University of Nebraska - Lincoln

DigitalCommons@University of Nebraska - Lincoln

Habitat Preferences of Migrant and Wintering Northern Harriers in Northwestern Texas

\author{
Caroll D. Littlefield \\ Bioresearch Ranch \\ Douglas H. Johnson \\ USGS Northern Prairie Wildlife Research Center, Douglas_H_Johnson@usgs.gov
}

Follow this and additional works at: https://digitalcommons.unl.edu/usgsnpwrc

Part of the Other International and Area Studies Commons

Littlefield, Caroll D. and Johnson, Douglas H., "Habitat Preferences of Migrant and Wintering Northern Harriers in Northwestern Texas" (2005). USGS Northern Prairie Wildlife Research Center. 238.

https://digitalcommons.unl.edu/usgsnpwrc/238

This Article is brought to you for free and open access by the US Geological Survey at DigitalCommons@University of Nebraska - Lincoln. It has been accepted for inclusion in USGS Northern Prairie Wildlife Research Center by an authorized administrator of DigitalCommons@University of Nebraska - Lincoln. 


\title{
HABITAT PREFERENCES OF MIGRANT AND WINTERING NORTHERN HARRIERS IN NORTHWESTERN TEXAS
}

\author{
Carroll D. LitTlefield and Douglas H. Johnson*
}

\author{
The Bioresearch Ranch, P.O. Box 117, Rodeo, NM 88056 (CDL) \\ USGS Northern Prairie Wildlife Research Center, Jamestown, ND 58401 (DHJ) \\ Present address of DHJ: USGS Northern Prairie Wildlife Research Center, Department of Fisheries, Wildlife, and \\ Conservation Biology, 204 Hodson Hall, 1980 Folwell Avenue, University of Minnesota, St. Paul, MN 55108 \\ *Correspondent: Douglas_H_Johnson@usgs.gov
}

\begin{abstract}
We studied habitat preferences of northern harriers (Circus cyaneus) in 4 counties of the Southern High Plains of northwestern Texas from October 1989 to May 1995. Harriers generally arrived in late July and departed in April. They hunted over a variety of habitats in the study area but mainly in Conservation Reserve Program (CRP) grasslands and vegetated playa basins. CRP grasslands, playa basins, and shortgrass prairie were used disproportionately to their availability, whereas winter wheat was used less than its availability. Brown harriers (adult females or subadults of either sex) foraged in CRP about as often as adult males but more frequently in playas and prairies, whereas adult males foraged more in winter wheat. As underground water sources for irrigation continue to be depleted, agricultural practices are likely to change. Depending on how the land is used after irrigation ceases, harriers might benefit if CRP grasslands, vegetated playas, and shortgrass prairies persist. If dominant land use reverts to livestock grazing, however, the harrier population will be negatively affected.
\end{abstract}

RESUMEN-Estudiamos las preferencias de hábitat del gavilán norteño (Circus cyaneus) en cuatro condados de las praderas altas sureñas del noroeste de Texas desde octubre 1989 hasta mayo 1995. El gavilán norteño generalmente llega a fines de julio y se va en abril. Cazaron en una variedad de hábitats en la área de estudio pero principalmente en los pastizales del Conservation Reserve Program (CRP) y en las cuencas vegetadas de los lagos playas. Pastizales de CRP, cuencas de los lagos playa y praderas de pasto corto fueron usados desproporcionadamente a su disponibilidad, mientras que el trigal invernal fue usado menos que su disponibilidad. El gavilán norteño de coloración café (hembras adultas o subadultos de ambos sexos) forrajearon en CRP tan seguido como los machos adultos pero más frecuentemente en lagos playa y praderas, mientras que los machos adultos forrajearon más en trigales invernales. Así como el agua del subsuelo usada para irrigación continúa siendo mermada, las prácticas agrícolas tendrán que cambiar. Dependiendo de cómo es usada la tierra después de que la irrigación cese, los gavilanes norteños se pueden beneficiar si los pastizales de CRP, los lagos playa vegetados, y las praderas de pasto corto persisten. Por otro lado, si el uso de la tierra dominante se convierte a forrajeo de ganado, la población del gavilán norteño será afectada negativamente.

In many regions of the western United States, the northern harrier (Circus cyaneus) is a common wintering raptor, inhabiting a broad range of landscapes, such as deserts, dry prairie grasslands, croplands, pasturelands, fallow fields, and freshwater marshes. Two recognized concentration areas are the valleys of the northern Great Basin and the prairies and former prairies of the southern Great Plains, particularly those of eastern New Mexico and western Texas (Root, 1988). On the Southern High Plains of northwestern Texas, the north- ern harrier usually is the most abundant wintering raptor. Numbers vary annually, however, depending on local prey availability and weather conditions (e.g., Craighead and Craighead, 1956). Much of the Southern High Plains is now dominated by agriculture, with only $39 \%$ of the original shortgrass prairie remaining in 1992 (Haukos and Smith, 1994). Except on Muleshoe National Wildlife Refuge in Bailey County, most of the remnants have been heavily grazed by livestock. In addition, 19,340 closed drainage basins (termed playas) occur; 


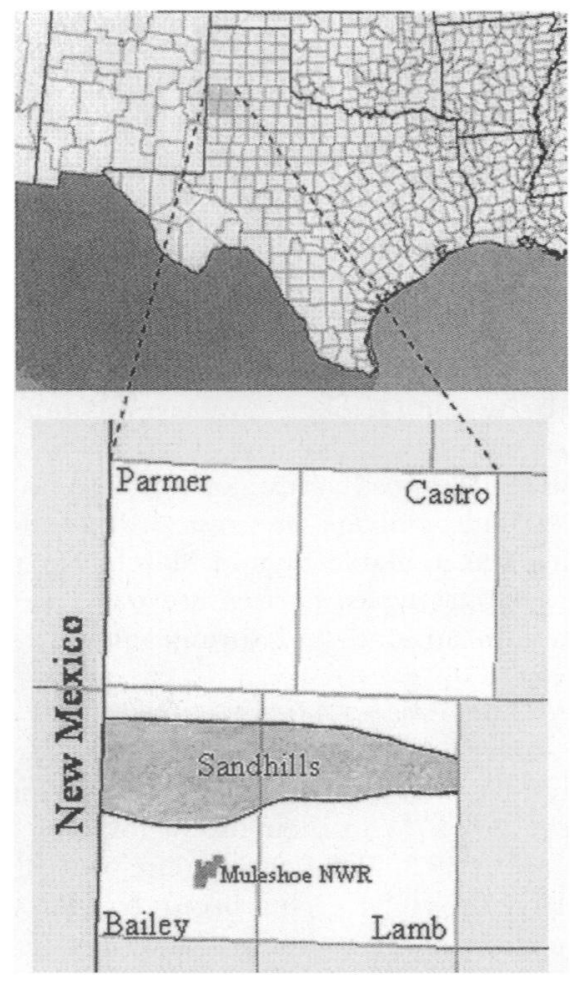

FIG. 1-Wintering northern harriers (Circus cyaneus) were studied in 4 counties of northwestern Texas from October 1989 to May 1995.

these closed systems average 6.3 ha in size (Haukos and Smith, 1994). This interspersion of croplands, grasslands, and playa basins creates a mosaic of habitats for small mammals, the principal prey of most wintering harriers (MacWhirter and Bildstein, 1996).

This study was conducted between October 1989 and May 1995. Principal objectives were to assess foraging habitat preferences for migrant and wintering harriers and to compare foraging preferences between adult males and brown harriers (adult females or subadults of either sex). Our intent was to provide information on harrier habitat use in a key North American wintering area at the close of the 1900 s, while underground water supplies from about 70,000 wells were still adequate to support irrigation of $20,000 \mathrm{~km}^{2}$ of cropland (Palacios, 1981).

Study Area AND Methods-Study Area-Our study areas were Bailey, Castro, Lamb, and Parmer counties in northwestern Texas (Fig. 1). These counties comprise more than 800,000 ha: $63 \%$ cropland, $16 \%$ rangeland, $16 \%$ Conservation Reserve Program (CRP) grassland, and $<2 \%$ in 2,954 playa basins (sensu Haukos and Smith, 1994; Guthery and Bryant, 1982). The Muleshoe Sandhills, a band of rolling hills and dunes, vegetated with native tallgrasses and shrubs, divides the northern irrigated agriculture region from the mostly dry-farmed southern region (Fig. 1). Irrigated sites north of the Muleshoe Sandhills support cotton, milo, corn, sugar beets, various vegetables, winter wheat, and alfalfa. In southern Lamb and Bailey counties, where underground water sources are limited, principal crops are cotton, milo, and winter wheat.

Elevations in this gently rolling study area range from 1,056 to $1,262 \mathrm{~m}$. The climate is semi-arid and continental, with mean annual precipitation varying from 430 to $450 \mathrm{~mm}$; most precipitation falls during May through June and August through October. The occasional snow is generally light and melts rapidly. Mean January minimum temperatures range from 5 to $7^{\circ} \mathrm{C}$; mean July maximums are 33 to $34^{\circ} \mathrm{C}$.

Methods-To calculate percentages of habitat types available, vehicle transects were conducted at different locations each year. Most transects ranged from 9 to $20 \mathrm{~km}$ in length and were dispersed throughout the 4-county area. Each transect was run once, except in the agricultural district of northern Lamb County, where 4 transects were surveyed annually to monitor crop changes. No major land-use changes occurred during the study, so we pooled data from all transects to calculate habitat availability. Many transects south of the Muleshoe Sandhills included CRP grasslands, a habitat type that currently covers a large percentage of once dry-farmed agricultural land. About the only consistent type of change noted was annual corn-cotton rotations within fields, which left percentages generally unchanged. No changes among years occurred for CRP grasslands, prairies, playa basins, or any other non-agriculture land-use.

Northern harriers searching for (gliding, transect flying, or quartering; MacWhirter and Bildstein, 1996) or handling prey were used in the analysis. Most data were collected on the same transects used to estimate habitat availability from the time birds first arrived until they departed. For the study, the autumn period extended from arrival through November, winter from 1 December through February, and spring from 1 March until harriers left. Habitat was recorded where a foraging harrier was first sighted. In most years, data were collected continuously from the time harriers arrived until they departed. No data were collected during 14 November 1991 to 6 March 1992 and 14 October 1992 to 18 February 1993.

We compared the proportion of each habitat used to the proportion of habitat available by constructing 95\% Bonferroni confidence intervals (Byers et 
al.,1984) around the proportion-of-use value and determining if the proportion available was within that confidence interval. Habitat types for which the confidence interval for harrier use exceeded the value for availability were deemed to be selected for; habitats with confidence intervals for use lower than the availability were avoided.

\section{Results-Northern Harrier Chronology-} Northern harriers frequently arrived in late July; during this study, autumn migrants were first recorded between 23 July and 10 August. Peak autumn passage was usually during 10 to 25 October, with the majority of transients gone by 1 December. Most (68 to $85 \%$ ) wintering birds were brown harriers.

Spring transients (northbound, rapidly and high-flying harriers) first appeared between 4 and 24 February. Peak spring passage was generally during 5 to $25 \mathrm{March}$, with the majority of birds gone by 20 April.

Overall Northern Harrier Habitat Use-A total of 1,281 northern harrier foraging observations were used in the analysis. The number of distinct individuals was unknown, because harriers on the Southern High Plains reportedly are nomadic, not remaining in an area for any extended period (Schibler, 1981). For the 24 vegetative types and agricultural regimes where the species was recorded, the majority were in either CRP grasslands $(n=274)$, vegetated playa basins $(n=269)$, winter wheat $(n=229)$, or shortgrass prairie $(n=107)$. These 4 types received $69 \%$ of the harrier use, yet constituted only $39 \%$ of the available habitat. CRP grasslands, playa basins, shortgrass prairies, and weedy homesites (33 of 40 of which had been abandoned) were used disproportionately more than their availability, whereas winter wheat was used less than its availability (Fig. 2). Types with moderate use, or use in proportion to availability, included unharvested cotton, fallow herbaceous fields, pasture, alfalfa, sugar beet, and milo (Fig. 2). Tilled stubble, cotton stubble, bare plowed fields, corn stubble, corn stubble planted to wheat, and plowed cotton received little use by harriers, relative to availability.

Seasonal Variation in Habitat Use-Harrier use of certain habitat types varied by season. Winter wheat, for example, increased in importance in spring, after seedlings had grown to sufficient height to provide concealing cover for small mammals, as well as vesper sparrows (Poocetes gramineus), Savannah sparrows (Passerculus sandwichensis), and meadowlarks (Sturnella). As birds shifted to wheat, use of playa basins decreased. Harriers frequently hunted in cotton in August and September, probably because dense herbaceous cover attracted both small mammals and passerine birds. Few harriers, however, were recorded in cotton after leaf-fall or following application of pesticides; usually by mid October, preharvest cotton was no longer used. Harriers also hunted to a minor extent in postharvest corn in autumn and winter but, as tillage progressed, little of this habitat was available by mid March. For most other habitat types, harrier use was generally highest in autumn and spring and lowest in winter.

Differences between Adult Male and Brown Harriers in Foraging Sites-Brown adult females and subadults $(n=1,006)$ differed from adult males $(n=275)$ in their use of foraging habitats $\left(\chi^{2}=58.3, P<0.0001\right)$. Use of CRP was similar ( 20.7 vs. $24 \%$ ), but brown harriers were more frequent on native prairie (9.5 vs. $4.4 \%)$ and playas (23.3 vs. $6.6 \%$ ) and less common in winter wheat ( 16.3 vs. $23.6 \%$ ) than adult males.

DISCUSSION-The northern harrier is an abundant migrant and common winter resident on the northwestern Texas plains. Although wintering harriers were noted in a variety of habitats, vegetated playas and CRP grasslands were most heavily used. Vegetation in these 2 habitat types generally should provide adequate food and cover for small mammals, particularly cotton rats (Sigmodon hispi$d u s$ ), which were also important in a Florida study (Collopy and Bildstein, 1987), house mice (Mus musculus), North American deermice (Peromyscus maniculatus), and western harvest mice (Reithrodontomys megalotis). A regional outbreak of hantavirus pulmonary syndrome precluded small-mammal trapping in this study, but observations suggested that cotton rats were an important prey item; less frequently, smaller mammals were noted being transported or consumed by harriers (C. D. Littlefield, pers. observ.). Avian prey did not seem to be a major food resource, except for waterfowl carcasses in shallow water bodies infested with cholera (Pasturella multoceda).

Migrant and wintering harriers in north- 


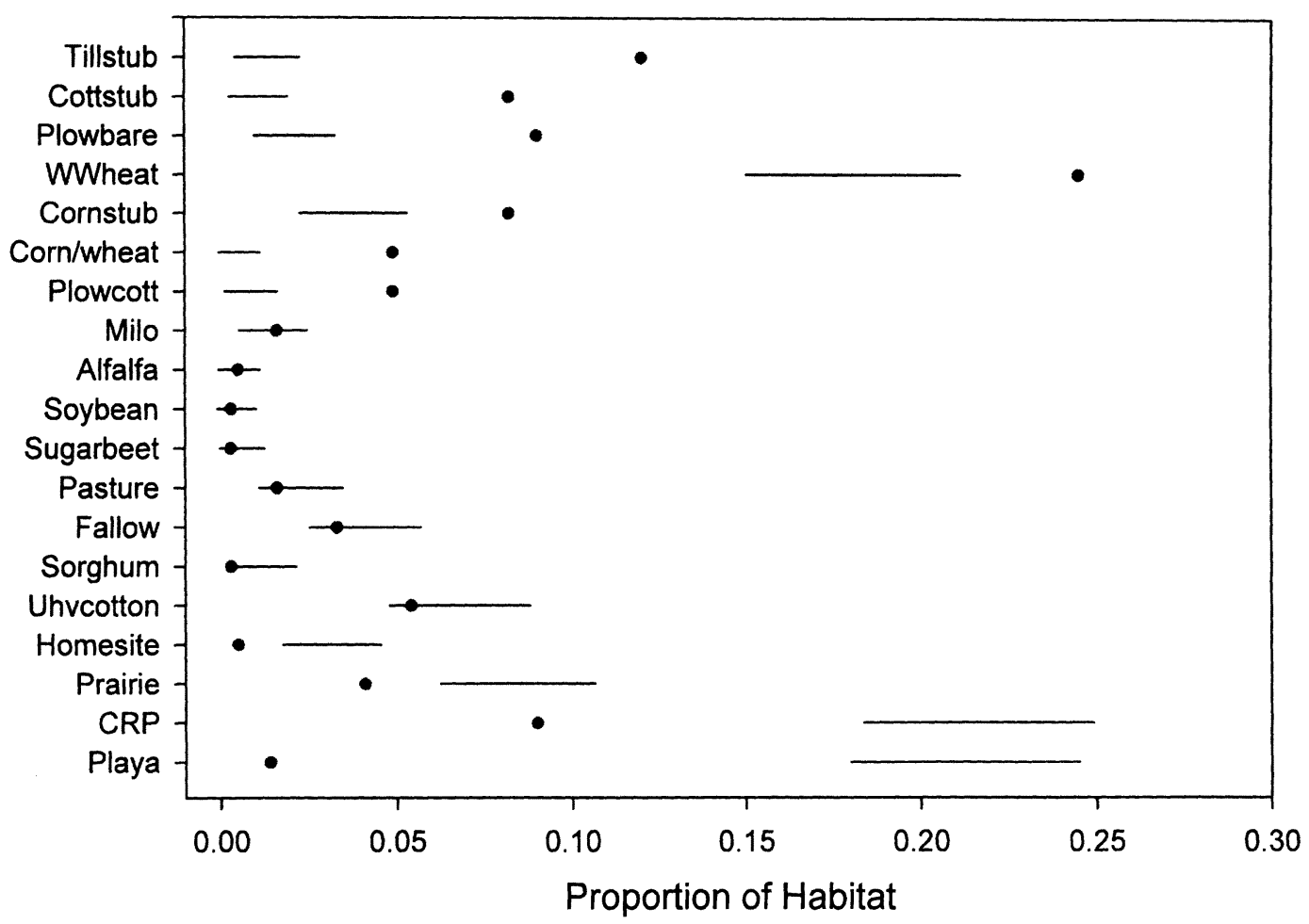

FIG. 2-Proportion of habitat available (dot) and used (line, representing 95\% Bonferroni confidence interval) by wintering northern harriers (Circus cyaneus) in northwestern Texas, October 1989 to May 1995. Habitats showing the dot to the left of the line were used significantly more often than their availability, habitats with the dot to the right of the line were used less than their availability, and the use of habitats with the dot within the line did not differ significantly from availability. Habitats (top to bottom) are tilled (corn) stubble, cotton stubble, plowed bare soil, winter wheat, corn stubble, corn stubble planted to wheat, plowed cotton, milo, alfalfa, soybeans, sugar beets, pasture, fallow, sorghum, unharvested cotton, home sites, shortgrass prairie, Conservation Reserve Program grasslands, and playa basins.

western Texas differed somewhat in foraging habitat preferences from harriers in agricultural regions in the north-central United States. Foraging harriers in Ohio preferred fallow fields and fields with corn and wheat stubble (Bildstein, 1987); in northwestern Texas, fallow areas had moderate use, but birds showed no particular preference for the type. Corn stubble generally received little use, perhaps reflecting local farming practices; most corn stubble was tilled or planted to winter wheat soon after harvest. In Ohio, stubble apparently remained idle through much of the winter. Most wheat stubble on the Southern High Plains was tilled before harriers arrived in autumn. CRP grasslands, playas, new-growth winter wheat, and prairies were important foraging habitats in this study, with preferences shown for CRP, playas, and prairies, but not wheat. Local harriers, particularly males, also differed from Ohio birds by foraging at homesites more than expected. Texas homesites, especially abandoned ones, probably had a greater amount of associated vegetative cover than those in Ohio. Extensive stands of summercypress (Kochia scoparia) usually grew at abandoned sites in Texas and provided habitat for both small mammals and passerines.

Brown and adult male harriers differed somewhat in their habitat use. Generally, adult males avoided habitats being extensively used by adult females; females were noted on several occasions evicting males from foraging sites. Although primarily nomadic, some adult females seemed to establish winter territories at favorable locations, defending these sites for a few days to several weeks. Adult males, conversely, were floaters, not spending time at any 
particular location, generally moving from site to site until they detected prey. Similar contrasts in behavior have been reported from other locations between adult males and adult females (Temeles, 1986) and between adult males and juveniles (Bildstein, 1987).

As water mining further depletes local underground sources, irrigated croplands might drastically decline in coverage on the Southern High Plains of Texas. Many irrigation wells were pumping much less water in the late 1990 s than they were in the 1980 s (C. D. Littlefield, pers. observ.). It remains to be seen what impact water depletion and subsequent vegetation changes will have on local wintering harriers, but, depending on how the land is used after irrigation ceases, it is possible that the birds might benefit. In this study, the 2 most important foraging habitats (CRP and playas) supported $42 \%$ of the harrier use; future harrier abundance might well depend on the continued availability of these 2 habitat types. With underground water sources declining, it is likely that additional hectares of irrigated cropland will be enrolled into CRP and converted to grasslands, if funding for the CRP continues. Many playas within these new enrollments also would be protected, thus increasing available habitat for harriers as well as associated species. Conversely, if playas are not protected in some way, they likely will be further degraded, particularly if the dominant land-use reverts to livestock grazing. Northern harriers reduce their use of livestock-grazed grasslands (Littlefield and Thompson, 1987; MacWhirter and Bildstein, 1996) and avoid playa basins with short vegetation (Schibler, 1981).

We provide information on northern harrier foraging habitat at a time when a fairly large percentage of the land base in the Southern High Plains of Texas was irrigated cropland. Future assessments perhaps will be able to compare harrier use after underground water supplies have been depleted and new agricultural practices introduced.

We thank J. D. Enriquez for providing the Spanish translation of the abstract; B. R. Euliss for drafting the figures; and K. L. Bildstein, J. T. Garcia, and R. T. Scholes for comments on earlier drafts of the manuscript

\section{Literature Cited}

BILdstein, K. L. 1987. Behavioral ecology of redtailed hawks (Buteo jamaicensis), rough-legged hawks (Buteo lagopus), northern harriers (Circus cyaneus), and American kestrels (Falco sparverius) in south central Ohio. Ohio Biological Survey, Biological Notes 18.

Byers, C. R., R. K. Steinhorst, and P. R. Krausman. 1984. Clarification of a technique for analysis of utilization-availability data. Journal of Wildlife Management 48:1050-1053.

Collopy, M. W., ANd K. L. Bildstein. 1987. Foraging behavior of northern harriers wintering in southeastern salt and freshwater marshes. Auk 104:1116.

Craighead, J. J., and F. C. Craighead, Jr. 1956. Hawks, owls, and wildlife. Stackpole Books, New York.

Guthery, F. S., AND F. C. BRyAnt. 1982. Status of playas in the Southern Great Plains. Wildlife Society Bulletin 10:309-317.

Haukos, D. A., AND L. M. SMITH. 1994. The importance of playa wetlands to biodiversity of the Southern High Plains. Landscape and Urban Planning 28:83-98.

LitTlefield, C. D., AND S. P. Thompson. 1987. Winter habitat preferences of northern harriers on Malheur National Wildlife Refuge, Oregon. Oregon Birds 13:156-164.

MaCWhirter, R. B., AND K. L. Bildstein. 1996. Northern harrier (Circus cyaneus). In: A. Poole and F. Gill, editors. The birds of North America, number 210. Academy of Natural Sciences, Philadelphia, Pennsylvania, and American Ornithologists' Union, Washington, D.C.

PAíacios, N. 1981. Llano Estacado playa lake water resources study. In: J. S. Barclay and W. V. White, editors. Playa Lakes Symposium. FWS/OBS-81/ 07. United States Fish and Wildlife Service, Biology Service Program, Fort Worth, Texas. Pages 15-20.

Root, T. 1988. Atlas of wintering North American birds: an analysis of Christmas Bird Count data. University of Chicago Press, Chicago, Illinois.

SCHIBLER, M. D. 1981. Some aspects of the winter ecology of harriers on the Texas High Plains. Unpublished M.S. thesis, Texas Tech University, Lubbock.

TEMELES, E. J. 1986. Reversed sexual size dimorphism: effect on resource defense and foraging behaviors of nonbreeding northern harriers. Auk 103:70-78.

Submitted 23 December 2003. Accepted 9 March 2005. Associate Editor was Timothy Brush. 